\title{
The labor market in Canada, 2000-2016
}

\section{A strong resource boom that benefited Canada's economy and labor market was followed by a painful adjustment}

Keywords: unemployment, resource boom, income inequality, Canada, job polarization

\section{ELEVATOR PITCH}

During the 2000-2016 period, Canada's economy and labor market performed well. An important element in this success was the strong resource boom that lasted from the late 1990s to 2014. Since that time the economy and labor market have been undergoing a painful adjustment, a process that is now essentially complete. A good rule of thumb when examining many aspects of the labor market, such as the extent of unionization and the level of the minimum wage relative to the median wage, is that Canada is situated roughly halfway between the US and Europe.

\section{KEY FINDINGS}

\section{Pros}

(† Economic downturns during 2000-2016 were much less pronounced than during the 1980s and 1990s.

- Recent recessions in Canada have been much milder than in the US and much of Europe.

(૯) Real wage gains from 2000 to 2016 were substantial-and much greater than during the preceding 20 years.

(- After rising markedly during the 1980s and 1990s, income inequality has been relatively stable since 2000.

$\oplus$ The male-female earnings gap has continued to decline.

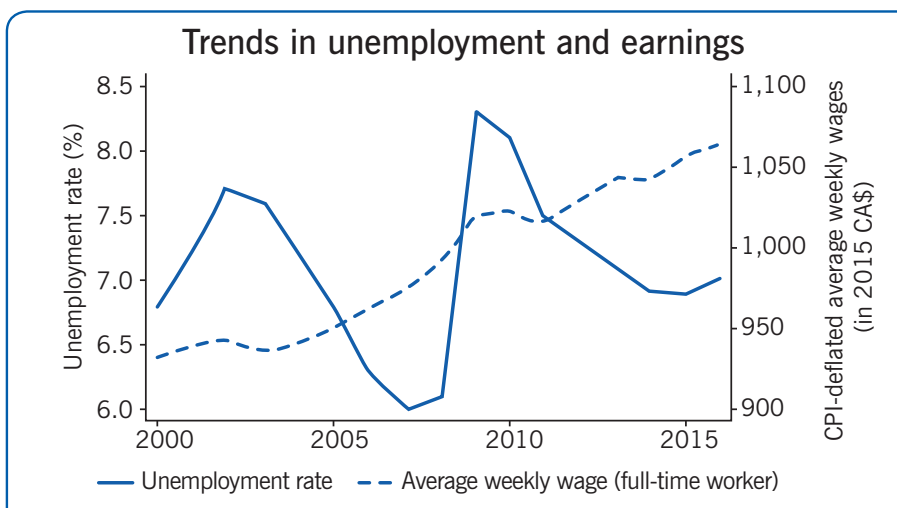

Source: Author's own calculations based on Statistics Canada, CANISM Tables 282-0225, 282-0072, and 282-0074. Online at: http://www5. statcan.gc.ca/cansim/

\section{Cons}

- Since the end of the resource boom in 2014, the labor market has been undergoing substantial labor reallocation due to job losses and unemployment in resource rich regions.

- Real earnings gains have been very unevenly shared, with especially large increases at the top of the income distribution.

- The labor market became increasingly polarized in terms of "good" (high-skill and high-paid) and "bad" jobs between 1970 and 2000, though it has since stabilized.

- With the resource boom over, one concern is that income inequality and job polarization will resume growing over time.

\section{AUTHOR'S MAIN MESSAGE}

Canada's labor market has performed well since 2000, and avoided the worst effects of the 2008 financial crisis. Since 2000, real earnings have grown rapidly and income inequality has remained relatively stable. Despite these positive outcomes, earnings gains at the top $10 \%$ of the distribution substantially exceeded those among the bottom $90 \%$. The resource boom and the accompanying high value of the Canadian dollar also brought about substantial reallocation of labor and other resources. Looking ahead, it will be interesting to see whether "inclusive growth"-economic growth combined with gains that are widely shared-can be achieved. 


\section{MOTIVATION}

Knowing the facts about a labor market is crucial for understanding labor market policy and for having a relevant background for discussing labor markets worldwide. Equally important is knowing which aspects of a country's labor market are performing well and which ones are doing poorly. This article provides these facts and background for Canada, a small open economy that relies heavily on international trade and which has a large resource sector.

\section{DISCUSSION OF PROS AND CONS}

\section{Aggregate issues}

Although this article focuses on the period 2000-2016, some of the discussion covers the period 1980-2016 in order to provide additional perspective on differences in aggregate labor market behavior between the 1980s and 1990s and the period since 2000. Differences between Canada and the US in terms of unemployment provide additional perspective. For the latter, Figure 1 plots the Canadian unemployment rate measured using US concepts, since there are some small differences between the surveys that produce these data. The highlighted areas correspond to economic slowdowns in the two countries.

Canadian economic downturns have been much less severe since 2000 than they were before. The recessions of the early 1980s and early 1990s were Canada's two worst recessions of the post-war period. As illustrated in Figure 1, increases in the unemployment rate and long-term unemployment were much smaller after 2000 than during the 19811982 and 1990-1992 recessions. The unemployment rate peaked at much higher levels in 1983 and 1993 than subsequently, and the incidence of long-term unemployment hit postwar highs that have not been experienced since 2000. Declines in GDP and employment were also much greater in the earlier downturns.

Figure 1. Canada and US unemployment rates and percentage of long-term unemployed

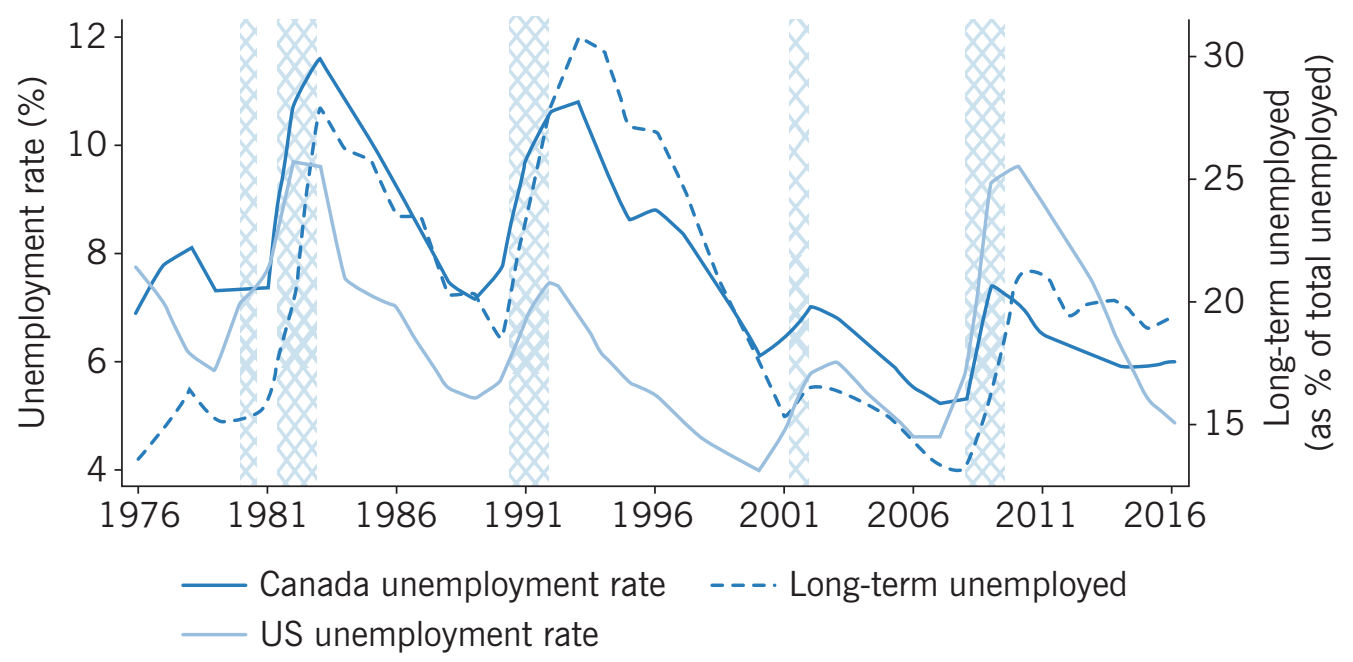

Note: Long-term unemployment defined as $27+$ weeks. Canadian unemployment rate measured using US concepts. Highlighted areas indicate periods of recession and slowdown.

Source: Unemployment rate: Statistics Canada, CANSIM Table 282-0086; long-term unemployed: author's own calculations based on CANSIM Table 282-0048. Online at http://www5.statcan.gc.ca/cansim/; US unemployment rate: US Department of Labor unemployment statistics. Online at: https://www.bls.gov/data/\#unemployment 
The Canadian and US economies are highly integrated, and trade with the US constitutes a substantial amount of Canada's economic activity. However, Canada's economy is only one-tenth the size of the US's, so is heavily influenced by developments south of the border. As former Prime Minister Pierre Elliot Trudeau stated, "When the US sneezes, Canada catches a cold." This statement certainly applied in the 1980s and 1990s, but since 2000 downturns have hit much harder south of the border. In 2001 the US experienced a recession associated with the IT crash; Canada, meanwhile, had a mild slowdown that lasted only one quarter, so was not officially a recession. Moreover, unemployment rose much more in the US than in Canada, and the unemployment rate gap between the countries narrowed.

During the Great Recession associated with the 2008 financial crisis, unemployment increased substantially more in the US than in Canada, reversing the previous pattern of higher unemployment in Canada. Additionally, Canada's incidence of long-term unemployment increased much less than in the US.

Since the end of the resource boom in 2014, Canada has experienced a period of slow overall growth, a decline in the value of its currency, substantial reallocation of labor resources out of the resource-rich regions (Alberta, Saskatchewan, and Newfoundland) and a gradual recovery of employment and output in central Canada (Ontario and Quebec). The unemployment rate and incidence of long-term unemployment have been relatively stable, while US unemployment has fallen substantially, so that in 2015 the US unemployment rate again dropped below its Canadian counterpart.

\section{Labor force participation-Aggregate, by gender and by age}

Figure 2 shows the aggregate labor force participation rate over the period 2000-2016, together with breakdowns by gender and age. The aggregate rate showed little change, with almost identical levels of 65.8 in 2000 and 65.7 in 2016. Underlying this apparent stability, however, were noteworthy developments. At the aggregate level, participation rose from 2000 to 2008 (a period of buoyant economic conditions) and declined from 2008 to 2016 (after the financial crisis and the end of the resource boom). These changes are thus consistent with the view that recent movements in participation are driven primarily by aggregate economic conditions. However, further examination indicates that trends in participation among different age groups also play important roles.

Participation among prime-age men (aged 25-54 years) has been remarkably stable since 2000. The rate dipped slightly during the 2008-2009 recession, but by 2016 returned to its 2000 level of $91 \%$. For women aged 25-54, labor force participation increased by almost four percentage points, with most of this increase occurring from 2000 to 2008 when economic conditions were more favorable. The rise in female participation is, of course, a continuation of earlier trends. Since 2000 it was further encouraged by enhancements of "family-friendly" policies such as greater availability of subsidized daycare.

Combining women and men aged 25-54 (not shown in the figure) yields an increase of 1.7 percentage points in labor force participation since 2000. The combination of stability in aggregate participation and moderate gains in participation of prime-age workers contrasts sharply with the US, where a substantial decline in participation occurred, a development that has received considerable attention.

Figure 2 also shows participation trends for young adults (those between 15 and 24 years of age) and older workers (55+). Among young workers, the levels and changes in 
Figure 2. Labour force participation rates

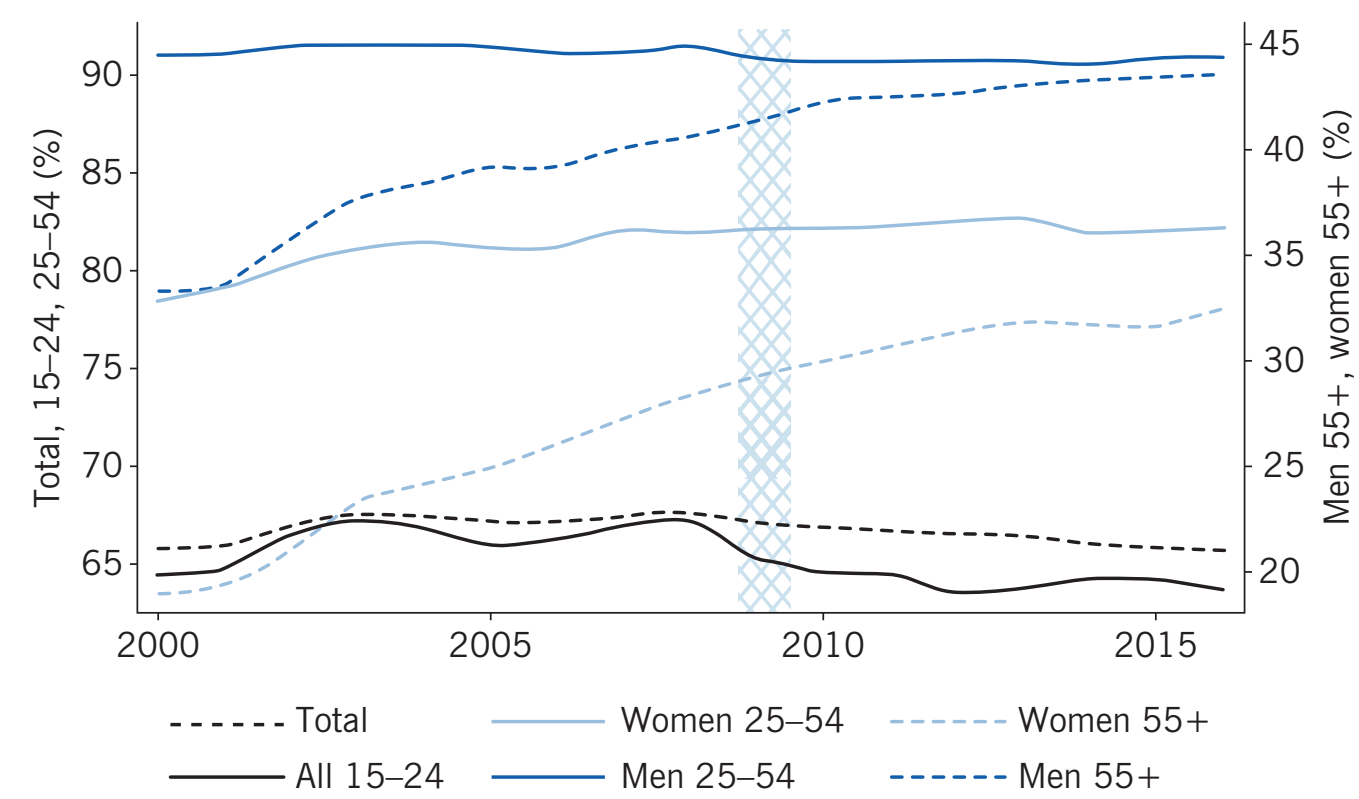

Note: Highlighted area indicates period of recession.

Source: Statistics Canada, CANSIM Table 282-0002. Online at: http://www5.statcan.gc.ca/cansim/

participation are very similar for men and women, so the combined series is shown in Figure 2. However, there are clear gender differences in the older age group, so separate series are shown.

Participation of 15-24 year olds rose by almost three percentage points during the period of strong economic growth in 2000-2008, but fell substantially during the 2008-2009 recession before leveling off, resulting in a very small overall decline from $64.4 \%$ in 2000 to $63.7 \%$ in 2016 . The rise during the $2000-2008$ period is consistent with evidence from previous resource booms that young adults (especially young men) become more likely to choose work over school when they can earn unusually high salaries.

Policy concerns were voiced during this period that young men were leaving school "too early" (especially before completing high school) in the resource-rich regions, and that doing so might not be in their (or society's) best long-term interests. While this may have been a legitimate concern, analysis of previous resource booms concludes that many of those who leave school early subsequently return to it, indicating that temporarily high earnings alter the timing, but not necessarily the total amount, of education acquired [1]. The substantial decline in this age group's participation after 2008 is consistent with this behavior, and more generally with the finding that teenagers and young adults stay in school longer (or return to school) during periods of weak economic activity.

Labor force participation rates of those aged 55 or over are much lower than for other groups (see Figure 2). After declining for many years, participation rates for older men bottomed out in the 1990s and have been rising since. The increase from 2000 to 2016 of more than ten percentage points is thus a continuation of this recent trend. The increase for women in this age group is even more substantial-from $19.0 \%$ in 2000 to $32.4 \%$ in 2016. The front end of the baby-boom generation is driving these large increases in participation, which appear to be attributable to several factors. Key contributors include 
Figure 3. Unemployment rates by age group and gender

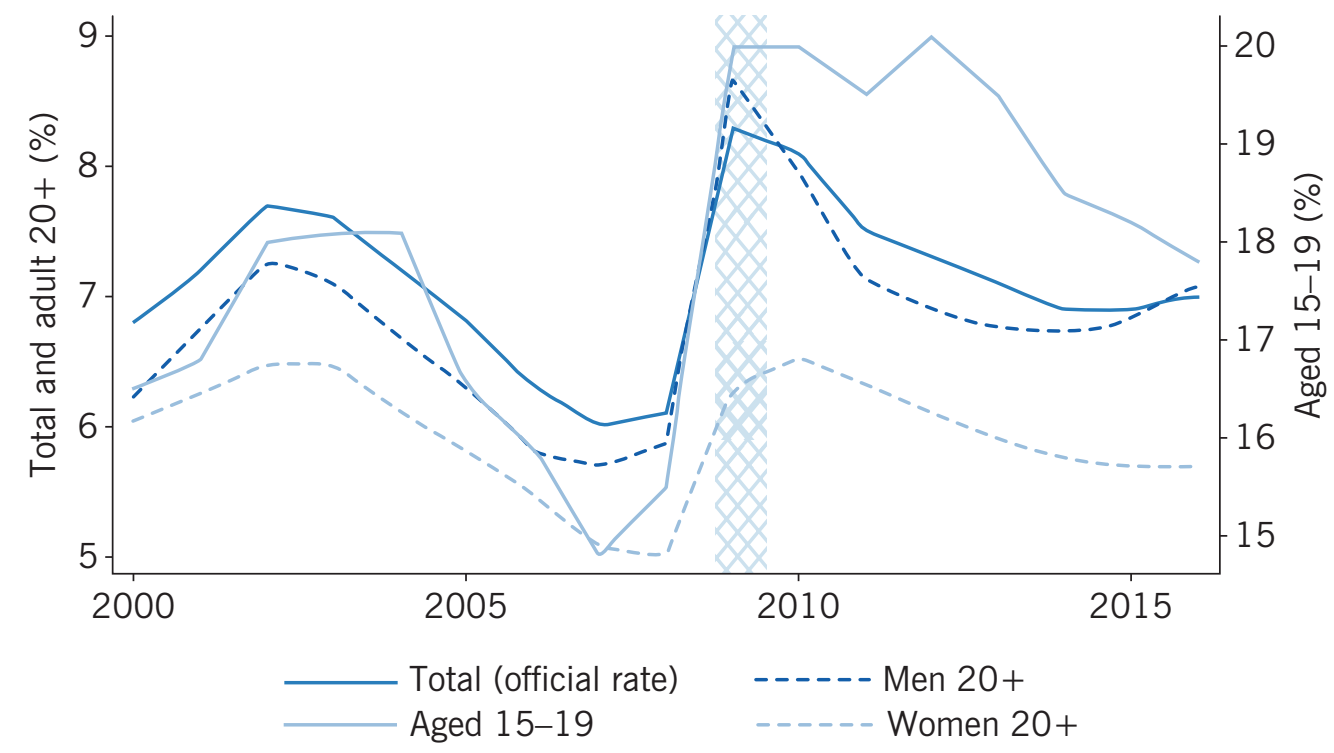

Note: Highlighted area indicates period of recession.

Source: Official rate: Statistics Canada, CANSIM Table 282-0086; women 20+ and men 20+: author's own calculations based on CANSIM Table 282-0002; aged 15-19: CANSIM Table 282-0002. Online at: http://www5. statcan.gc.ca/cansim/

greater longevity together with declining pension coverage (especially in the private sector) and a shift away from defined benefit pension plans toward defined contribution plans. Policy changes have also played a role; for example, the previous single retirement age of 65 (with some options for earlier retirement with a reduced pension) in the Canada Pension Plan was replaced by a "retirement window" from age 60 to 70 and a sliding payment schedule. Similarly, mandatory retirement is now banned throughout the country. The rise in female participation among older women is partly driven by women returning to the labor force after child rearing, and wanting to remain actively employed for longer thereafter. Canadian evidence indicates that this also results in married men remaining employed longer because of a desire for spouses to retire at similar points in time [2].

\section{The demographics of unemployment-Age and gender}

Youth unemployment rates in Canada are typically two to three times those of adults, principally due to substantially more turnover and "churning" in the youth labor market. Offsetting the greater incidence of unemployment is its shorter duration among youthgenerally one-half to two-thirds that of adults-and substantially lower long-term unemployment-about one-half that of adults.

Figure 3 shows unemployment for youths (those aged 15-19) and other groups. Youth unemployment peaked at 20\% during the 2008-2009 recession, but the ratio of youth to total unemployment was the same (about 2.5) in 2009 as it was in 2000 and 2016. The only noteworthy departure from this relationship occurred during the recovery from the 2008-2009 recession-youth unemployment remained high (around 20\%) until 2012, whereas overall unemployment fell steadily after 2009.

The incidence of long-term unemployment among youths also remained low during the 2000-2016 period-approximately half that of adults. 
For unemployment rates of those aged 20 and older, prior to the 1980s, women had higher unemployment rates than men, principally due to much higher incidence of unemployment associated with more frequent labor force turnover. However, with female labor force attachment continuing to rise, male unemployment rates have exceeded those of females since the 1990s. As seen in the figure, this pattern is also evident during the 2000-2016 period. The gap between male and female unemployment rates widened substantially in 2008-2010, although it remained above its pre-recession level as the economy recovered and increased again with the end of the resource boom in 2014.

\section{Wage developments}

Weekly earnings reflect both the employee's hourly wage and hours worked per week. In most cases the focus is on full-time workers, those who work at least 30 hours per week at their main job and who exhibit the strongest attachment to the labor force. However, in some cases the data refer to all workers, either because of data availability or in order to provide additional information. The Labour Force Survey (LFS) data are representative of the adult population aged 15 and over.

\section{Aggregate developments}

Figure 4 reports two commonly used measures of change in real wages for representative workers: mean (or average) real wages and median real wages. Wages in nominal dollars are deflated by the Consumer Price Index (all items) to obtain real wages (in constant 2015 Canadian dollars).

Three features of the data in Figure 4 are noteworthy. First, the average wage exceeds the median wage for both hourly and weekly wages. This reflects the fact that some employees receive extremely high wages. The presence of these top earners pulls up the average wage but does not influence the median wage. Second, average real wage growth exceeds median wage growth by a substantial amount. This difference arises because wage gains were much larger for those at the top of the wage distribution than for those in the middle. A third salient feature is that all measures of real wages increase substantially over this 16-year period-increases range from $49 \%$ for the median hourly wage to $55 \%$ for the mean hourly wage, or from $3.1 \%$ to $3.5 \%$ per year. Compared to the $1980 \mathrm{~s}$ and $1990 \mathrm{~s}$, during which real wages grew very little [3], these are impressive gains. Gains were largest in the period 2003-2009, were interrupted by the 2008-2009 downturn and recovery, and then resumed, albeit at a slower pace, in 2011.

\section{Wage and income inequality}

After a prolonged period in which the distribution of income was remarkably stable, Canada-like many other industrialized countries-has experienced rising wage and income inequality since the late 1970s. Canada is in the middle of the pack in terms of income inequality compared to other OECD countries. The level of inequality is above that of most EU countries-especially the Scandinavian countries-but below that of others, such as Australia, Italy, Japan, the UK, and the US. Similarly, the extent to which inequality increased since the mid-1980s is average for the OECD, although in this case the countries that had larger increases include low-inequality countries, like Sweden, Finland, Denmark, and Germany, as well as Japan and the US [4]. However, some features of the Canadian experience are unique. 
Figure 4. Real wages for full-time workers (2015 CA\$)

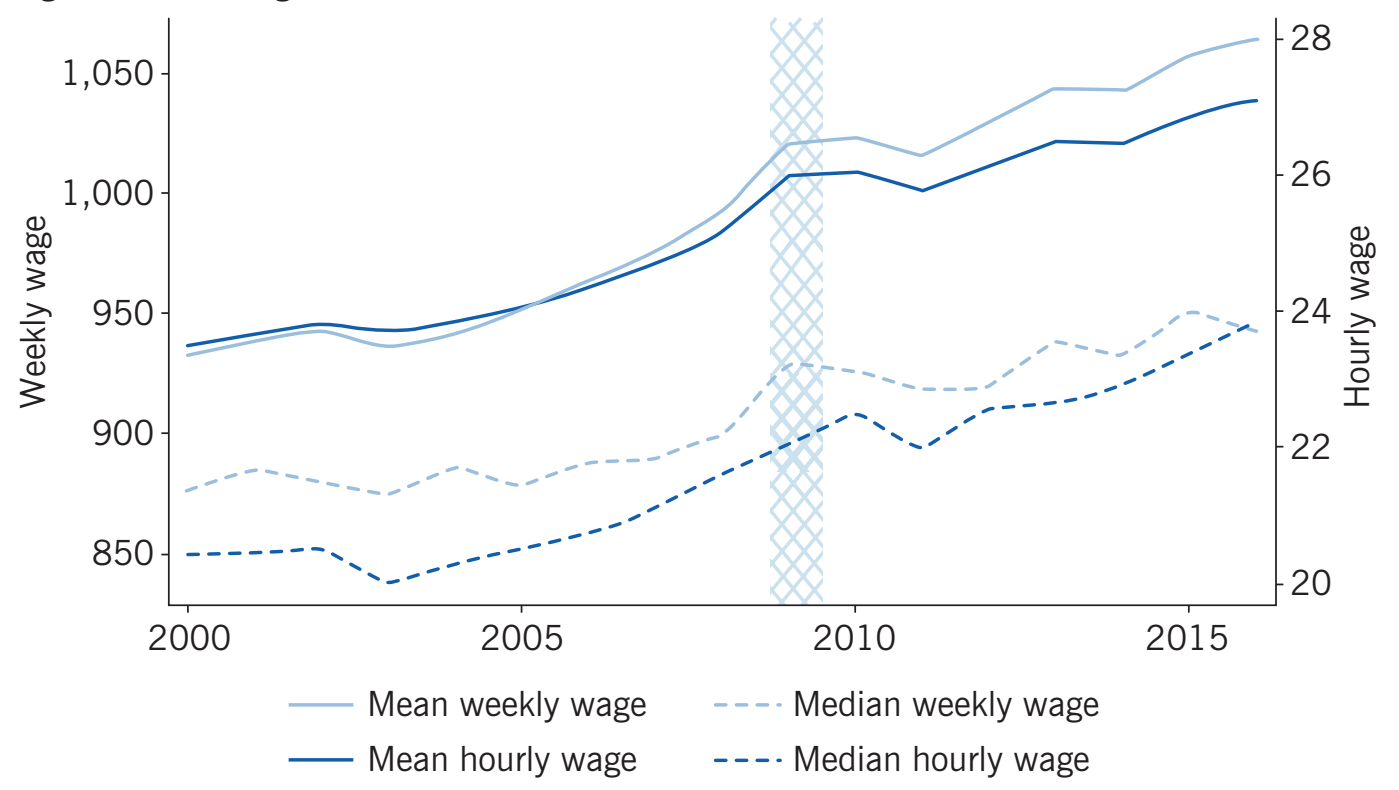

Note: Highlighted area indicates period of recession.

Source: Author's own calculations based on Statistics Canada, CANSIM Tables 282-0072 and 326-0021. Online at: http://www5.statcan.gc.ca/cansim/

Figure 5 provides several commonly used inequality measures over the period from 1980 to $2014 / 2015$ (the most recently available data). The first is the Gini coefficient for family market income before government transfers and taxes, adjusted for family size. Canada's Gini coefficient rose by $18 \%$ over this period, a substantial increase in a measure that is not easy to move. However, the growth in inequality was highly uneven. Inequality shot up during the 1981-1982 recession, declined gradually during the subsequent period of strong economic growth, but remained above its pre-recession level at the peak of the business cycle in 1989. The recession of the early 1990s brought another sharp increase, but inequality continued to rise during the subsequent expansion, principally because of major cutbacks in income support programs [5].

The remaining series in Figure 5 provide measures of income inequality at the individual level based on income tax returns. In Canada these are filed on an individual, not family, basis. Compared to survey data, advantages of these data include (i) less measurement error due to imperfect recall and non-response to income questions and (ii) absence of top-coding (which occurs when observations above a certain income level are censored for confidentiality reasons). However, tax data are less timely-2014 is the most recent year available-and for confidentiality reasons only aggregate measures are released. Figure 5 shows the shares of total income received by key segments of the income distribution: the bottom $50 \%$, top $10 \%$, top $1 \%$, and top $0.1 \%$.

Several features stand out. The share of income received by the bottom $50 \%$ declined from $14 \%$ to $10 \%$-a drop of almost $30 \%$-during the 1980 s and 1990 s but has been stable since 2000. Similarly, shares at the top of the income distribution rose sharply between 1982 and 2000, but have been unchanged or declined somewhat since. The largest gains in the 1980s and 1990s were achieved by those at the very top: percentage increases were $22 \%, 66 \%$, and $133 \%$ for the top $10 \%$, top $1 \%$, and top $0.1 \%$ respectively. However, since the turn of the century the share of income received by these top income groups has been relatively stable. 
Figure 5. Measures of income inequality

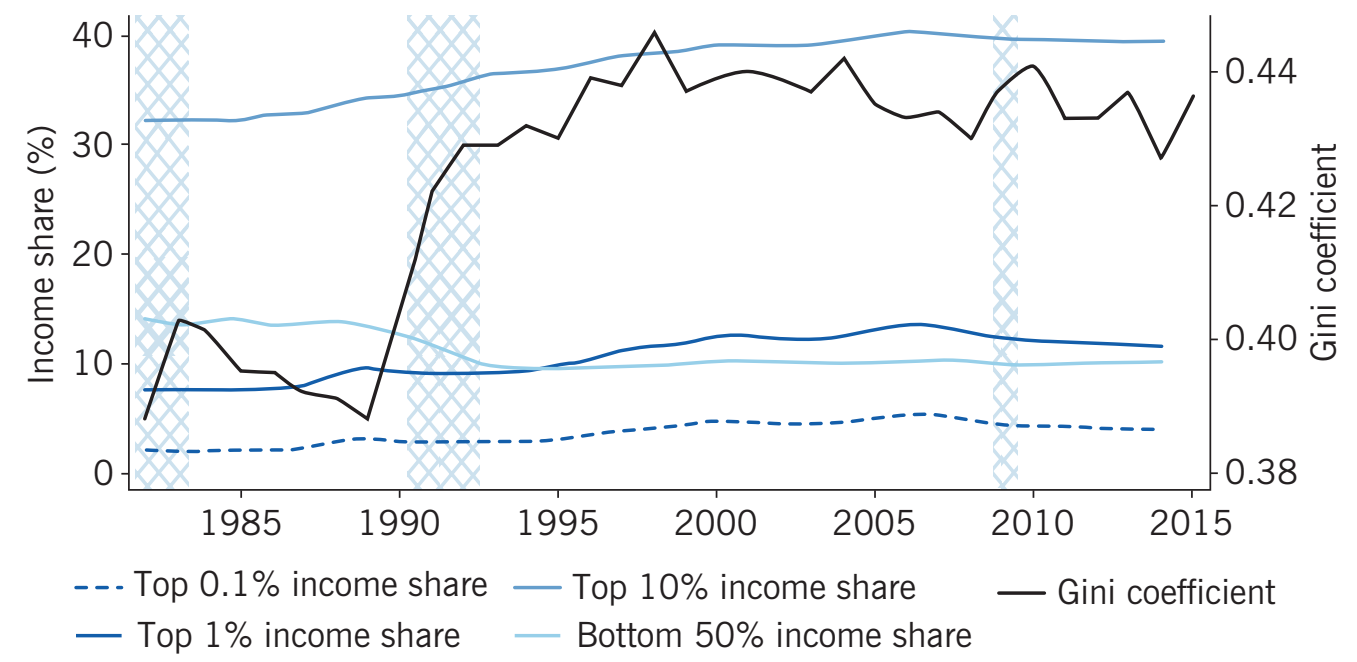

Note: Highlighted areas indicate periods of recession and slowdown. With the Gini coefficient, 0 refers to perfect/complete equality and 1 refers to perfect/complete inequality. The Gini coefficient is family market income before government transfers and taxes, adjusted for family size. Income shares are measured at the individual, not family, level.

Source: Statistics Canada, CANSIM Tables 204-0001 and 206-0033. Online at: http:/www5.statcan.gc.ca/cansim/ I Z A

Both the individual and family income measures illustrate a striking feature of Canada's experience that contrasts with trends in many other countries-income inequality stopped rising in the late 1990s, and remained relatively steady thereafter. Despite a modest increase in the Gini coefficient during the 2008-2009 financial crisis, its 2015 value is the same as in 1999.

A recent comprehensive examination of Canada's experience with income inequality attributes this leveling off of inequality growth to two principal factors [6]. One is the behavior of minimum wages, which vary by province in Canada. After falling during most of the 1980s and 1990s, real minimum wages have risen steadily since the early 2000s. Comparing the observed wage distribution in 2015 to an estimated counterfactual distribution in the absence of the increases in minimum wages concludes that these minimum wage increases had a large impact at the bottom of the wage distribution, especially in the bottom decile [7].

The second contributing factor was the resource boom that began in the late 1990s and lasted until mid-2014. Although the economic effects of this boom were regionally concentrated, its impacts were large enough to have significant effects at the national level [8]. The boom "lifted all boats" and had especially large impacts on wages for those with high school education or less. Indeed, if one focuses on Ontario and QuebecCanada's two most populous provinces-since 2000 income inequality increased in these non-resource-intensive regions in a manner similar to that of the US.

\section{Polarization of Canada's labor market}

In the US and many EU countries, rising wage inequality has been accompanied by employment polarization-with increasing numbers of workers employed either in high-paid "good jobs" or low-paid "bad jobs." These trends have also occurred in Canada [3], [9]. For example, the percentage of full-time, full-year workers at the bottom of the earnings distribution (those earning less than $50 \%$ of median earnings) increased from 
$8-9 \%$ in 1970 to $14 \%$ in 2005 for both men and women; meanwhile, the fraction of those at the top (earning more than $200 \%$ of the median) also rose, from $5-6 \%$ to $10 \%$. The size of the middle class (those earning between $50 \%$ and $150 \%$ of the median) fell from $75 \%$ to $63 \%$ over the same period [9]. Those with middle-class earnings continue to constitute the largest group, but the size of this category has fallen substantially over time. A similar finding holds if one classifies the groups by occupation: employment in cognitive task occupations, such as professional and management (which tend to be high skill and well paid), rose steadily over the 25-year period 1970-2005, as did employment in nonroutine manual occupations, such as sales and services (which tend to be poorly paid). In contrast, employment steadily declined in routine task occupations such as production, crafts, and operatives, as well as for secretaries and clerical jobs, which historically have paid relatively well [3].

Interestingly, however, job polarization stopped after 2000 [3]. The forces that contributed to the leveling off of rising wage inequality may also have halted, at least temporarily, the rising polarization of employment.

\section{Female-male earnings differences}

Female wage gains relative to males have been a pervasive feature of Canada's labor market for several decades. For example, comparison of the distributions of earnings improvements from 1970 to 2005 shows that women experienced substantially larger gains in real weekly earnings than men throughout most of the distribution [10]. At the 10 th percentile, women's earnings grew by $5 \%$ compared to a $10 \%$ decline for men; at the median, women's real earnings grew by $20 \%$, whereas men's earnings were flat over this 25 -year period. At the 90 th percentile the gains were more than $30 \%$ for women versus $18 \%$ for men.

Figure 6 plots the ratio of female to male hourly wages over the 2000-2016 period. Although complete equality has yet to be achieved, the gender gap continued to declinethe female-male ratio rose from 0.82 to 0.88 for full-time employees and from 0.81 to 0.86 for all employees.

Many factors have contributed to the narrowing of the gender wage gap-such as significantly more rapid gains in educational attainment among women than among men, substantial increases in female labor force attachment, and increasing representation of women in well-paid professions, such as medicine, law, and accounting. However, one factor that contributes to an ongoing gender gap in average earnings is the low representation of women among the highest earners. Men constitute the overwhelming majority of Canada's top 1\% [11]. Although their share has fallen steadily over time, it remained about $80 \%$ in 2011.

\section{Union-non-union wage differences}

The nature of Canada's unionized workforce has changed dramatically in recent decades. Unionization has fallen steadily in the private sector but risen or remained stable in the public sector. Union coverage rates are now five times higher in the public sector than the private sector. As a consequence, the majority (about 60\%) of the unionized workforce is in the public sector even though that sector accounts for only $20 \%$ of total employment. This change has been accompanied by a remarkable rise in the share of women among unionized employees-now over $50 \%$. 
Figure 6. Earnings ratios

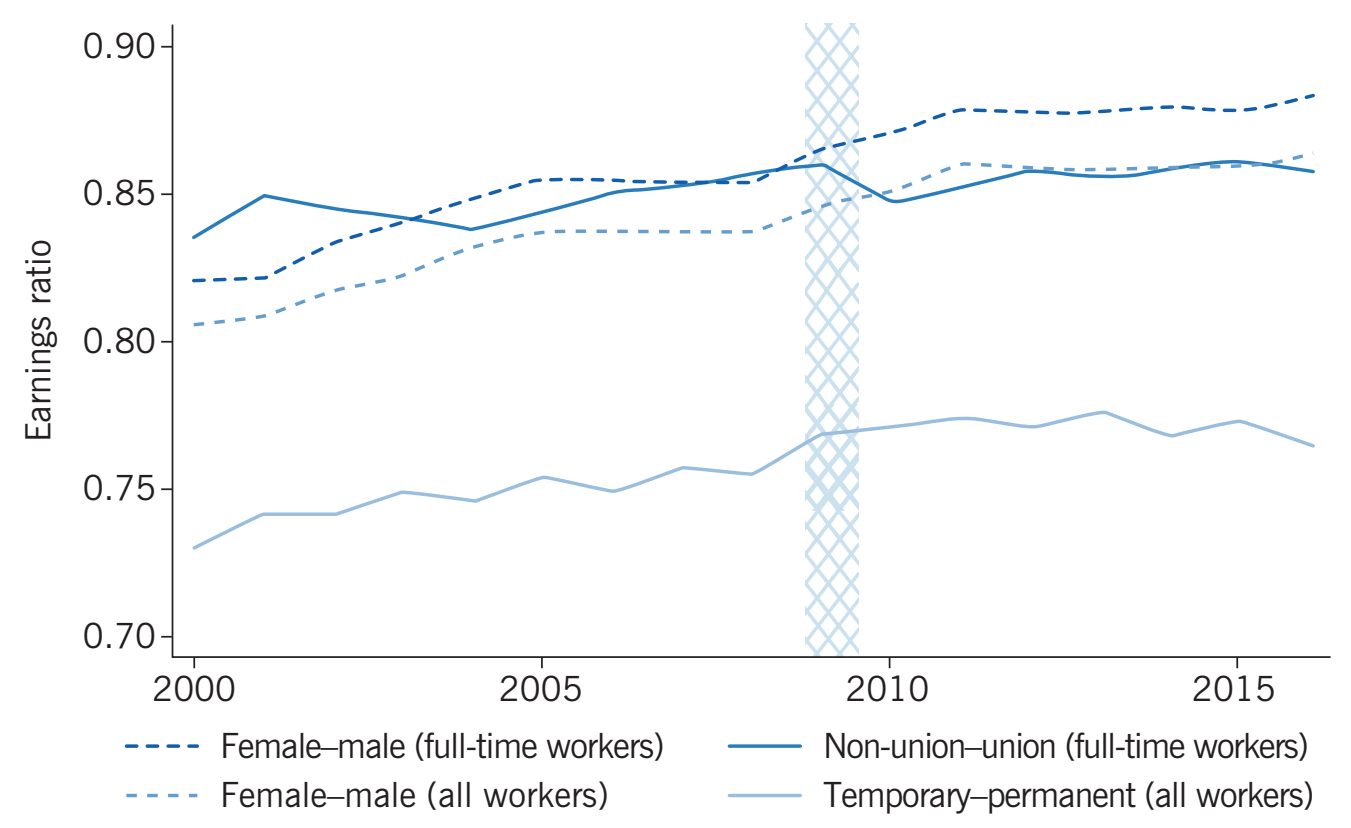

Note: Highlighted area indicates period of recession.

Source: Author's own calculations based on Statistics Canada, CANISM Tables 282-0225, 282-0072, and 282-0074. Online at: http://www5.statcan.gc.ca/cansim/

Despite these profound changes, the gap in hourly wages between union and non-union workers was quite stable at about 15 percentage points (Figure 6).

\section{Wage differences between permanent and temporary workers}

Another noteworthy change in Canada's labor market has been the growing importance of non-standard or contingent employment (temporary, contract, casual, and seasonal work). Since 1997 the monthly LFS has included questions relating to contingent employment. One concern about the increased prevalence of non-standard work is its association with lower wages and more limited non-wage benefits.

As indicated in Figure 6, the wage gap between temporary and permanent work is indeed large-more than 25 percentage points in 2000. However, it did narrow somewhat over the 2000-2016 period. Most of this narrowing took place prior to the 2008-2009 recession; since then the gap has been fairly stable.

\section{LIMITATIONS AND GAPS}

The most significant development in Canada's labor market is the dramatic rise in incomes at the top of the distribution. The vast majority of this income is payment for labor services, not other sources such as investment income [11]. However, traditional household surveys do not capture these earnings well because of top-coding in survey data as well as non-response to earnings questions. The best source of information is income tax data-the source used in the income share series shown in Figure 5. However, such data are only available with a time lag. Also, they are not made available in a manner 
that permits calculation of inequality measures such as 90/10 and 90/50 earnings differentials. Most important, many professionals receive earnings through personal private corporations, and only the amount taken out of the corporation each year is reported for tax purposes. Thus, the income shares in Figure 5 probably understate the rise in top incomes.

\section{SUMMARY AND POLICY ADVICE}

Canada's economy and labor market performed well during the 2000-2016 period relative to the previous two decades, as well as compared to many other countries. A key factor contributing to this performance was the 15 -year resource boom that recently ended. $A$ major concern is that trends that were ameliorated by the boom-rising inequality and low real wage growth for most workers-will re-emerge. At the bottom end, further moderate increases in real minimum wages appear warranted given evidence of their benefits for low-wage workers and limited adverse consequences. At the top, dramatic increases in earnings were driven primarily by two groups: senior managers-especially CEOs-and those employed in banking and finance. These huge gains appear to reflect the ability of these groups to extract economic rents during a period of financial deregulation and misguided attempts to tie senior managers' pay to performance, rather than to increased demand for scarce talent. Reducing the ability of these individuals to capture an outsized share of the rents produced by the economy is, to an important extent, a matter of improving compensation practices and corporate governance so that they operate more in the public interest. Because corporate governance in Canada is weak relative to other common law countries, like the UK and US, improvements are possible.

Canada's tax and transfer system-which is less progressive than the OECD averagecan also contribute. The recently elected federal government of Justin Trudeau started this process by raising income tax rates for high earners and lowering them for middle and low-income individuals. Although further tax rate adjustments are possible, it would be preferable to work toward eliminating unnecessary tax preferences used disproportionately by high earners.

\section{Acknowledgments}

The author thanks an anonymous referee and the IZA World of Labor editors for many helpful suggestions on earlier drafts. The author further thanks Yutong Lu for excellent research assistance, Nicole Fortin, David Green, and Thomas Lemieux for helpful comments and the SSHRC for financial support.

\section{Competing interests}

The IZA World of Labor project is committed to the IZA Guiding Principles of Research Integrity. The author declares to have observed these principles.

(c) W. Craig Riddell 


\section{REFERENCES}

\section{Further reading}

Green, D. A., W. C. Riddell, and F. St-Hilaire. Income Inequality: The Canadian Story. Montreal: Institute for Research on Public Policy, 2016.

Jones, S. R. G., and W. C. Riddell. Unemployment, Marginal Attachment and Labor Force Participation in Canada and the United States. IZA Discussion Paper No. 10769, May 2017.

\section{Key references}

[1] Emery, J. C. H., A. M. Ferrer, and D. A. Green. "Long-term consequences of natural resource booms for human capital accumulation.” ILR Review 65:3 (2012): 708-734.

[2] Schirle, T. "Why have the labor force participation rates of older men increased since the mid1990s?" Journal of Labor Economics 26:4 (2008): 549-594.

[3] Green, D. A., and B. M. Sand. "Has the Canadian labor market polarized?" Canadian Journal of Economics 48:2 (2015): 612-645.

[4] OECD Income Distribution and Poverty Database. Online at: http://www.oecd.org/social/ income-distribution-database.htm

[5] Frenette, M., D. A. Green, and K. Milligan. "Taxes, transfers and Canadian income inequality." Canadian Public Policy 35:4 (2009): 389-411.

[6] Green, D. A., W. C. Riddell, and F. St-Hilaire. "Income inequality in Canada: Driving forces, outcomes and policy." In: Green, D. A., W. C. Riddell, and F. St-Hilaire (eds). Income Inequality: The Canadian Story. Montreal: Institute for Research on Public Policy, 2016; pp. 1-76.

[7] Fortin, N. M., and T. Lemieux. "Changes in wage inequality in Canada: An interprovincial perspective." Canadian Journal of Economics 48:2 (2015): 682-713.

[8] Marchand, J. "The distributional impacts of an energy boom in Western Canada." Canadian Journal of Economics 48:2 (2015): 714-735.

[9] Beach, C. "What has happened to middle class earnings in Canada?" In: Green, D. A., W. C. Riddell, and F. St-Hilaire (eds). Income Inequality: The Canadian Story. Montreal: Institute for Research on Public Policy, 2016; pp. 157-176.

[10] Fortin, N., D. A. Green, T. Lemieux, K. Milligan, and W. C. Riddell. "Canadian inequality: Recent development and policy options." Canadian Public Policy 38:2 (2012): 121-145.

[11] Lemieux, T., and W. C. Riddell. "Who are Canada's top one percent?" In: Green, D. A., W. C. Riddell, and F. St-Hilaire (eds). Income Inequality: The Canadian Story. Montreal: Institute for Research on Public Policy, 2016; pp. 103-156.

\section{Online extras}

The full reference list for this article is available from:

https://wol.iza.org/articles/the-labor-market in-canada

View the evidence map for this article:

https://wol.iza.org/articles/the-labor-market in-canada/map 